\section{Global Journal of Foreign Language Teaching}

Volume 05, Issue 1, (2015) 52-64

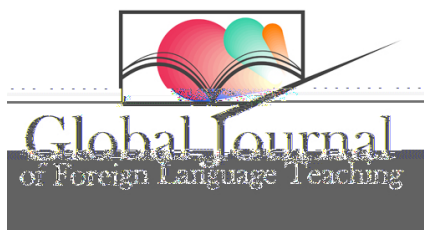

www.awer-center.org/gjflt/

\title{
The effect of language proficiency on the negotiation in peer review in EFL context
}

Bahram Mowlaie *, Department of Foreign Language, Islamic Azad University, Science and Research Branch, Tehran, Iran.

Parviz Maftoon, Department of Foreign Language, Islamic Azad University, Science and Research Branch, Tehran, Iran.

\section{Suggested Citation:}

Mowlaie, B. \& Maftoon, P. (2015). The effect of language proficiency on the negotiation in peer review in EFL context. Global Journal of Foreign Language Teaching. 5(1), 52-64.

Received 26 February, 2015; revised 11 March, 2015; accepted 13 April, 2015.

Selection and peer review under responsibility of Assoc. Prof Dr. Ali Rahimi, Bangkok University.

${ }^{\circledR} 2015$ SPROC LTD. Academic World Education \& Research Center. All rights reserved.

\begin{abstract}
The purpose of this study was to investigate the effect of language proficiency level on using negotiation categories in peer feedback in EFL context. Thirty high and thirty low proficient EFL learners participated in this study and their audiotaped negotiations were transcribed and analyzed based on Mendonça and Johnson's (1994) category. In four categories of restatement, suggestion, grammar correction, and explanation of opinion which were generated by the writers and the reviewers, although reviewers dominated the negotiation in both high and low proficient groups, in low proficient groups, the difference between the writers and the reviewer was more significant. In comprehension check and explanation categories used mainly by the writers, there was a significant difference in explanation between high and low proficient groups, but no such difference was found in comprehension check. In request for explanation category used mainly by the reviewers, no significant difference was found between the reviewers in high and low proficient group. The study has pedagogical implication for writing classes as it suggests audience awareness, critical thinking, and realization of output hypothesis as the pedagogically beneficial result of negotiation. It also suggests peer feedback as an alternative to teacher feedback.
\end{abstract}

Keywords: high and low proficient EFL learners, negotiation, peer feedback.

*ADDRESS FOR CORRESPONDENCE: Bahram Mowlaie, Department of Foreign Language, Islamic Azad University, Science and Research Branch, Tehran, Iran. E-mail address: bahrammowlaie@yahoo.com 
Mowlaie, B. \& Maftoon, P. (2015). The effect of language proficiency on the negotiation in peer review in EFL context. Global Journal of Foreign Language Teaching. 5(1), 52-64.

\section{Introduction}

Due to the shift of paradigm from product-oriented to process-oriented writing with successive revisions as the inextricable component (Flower \& Hayes, 1981) and from teacher feedback to peer feedback, the beneficial effect of peer review has been studied extensively (Kroll, 1991; Zamel, 1985). However, only recently has the exact mechanism of peer review and what exactly goes on during peer reviews attracted some attention (Mangelsdorf, 1992; Stanley, 1992). Because peer review has become a viable alternative to be deployed in L2 writing classes, researchers, writing teachers, and EFL learners need to be made aware of the negotiations that occur during peer reviews to enhance the quality of peer review by improving the quality of these negotiation moves.

Many researchers have argued that in L1 and EFL instructional settings the peer interactions that occur during peer reviews have cognitive and affective benefits because it is conducive to learner-centeredness (Lightbown \& Spada, 2006), real audience (Richards \& Rodgers, 2001), positive atmosphere, peers' self-confidence, involvement, accountability, and cooperative learning (Li, 2006; Riddle, 2003). Real audience is specifically important because according to Cazden (1988) it enables students to modify their attitudes in light of their peers' reactions and to establish a face-to-face relationship with their audience by giving and receiving feedback. According to Mangelsdorf (1989) by using their peer's review, EFL learners can test out and revise their hypotheses about the L2 in meaningful contexts to find the right words to express their ideas, and to negotiate with their audience about them. Kroll (1991), Leki (1990), Mangelsdorf (1989), and Zamel (1985), argue that the peer negotiation represents an important component of effective L2 writing instruction in L2 instructional settings. Mangelsdorf (1989) states that because of integration of speaking, writing, listening, and reading, peer negotiation can enhance the development of L2 learning in general.

Theoretical support for peer review comes from Vygotsky (1986) who regards language use, whether written or oral, a social act and, therefore, peer interactions merge the cognitive and social aspects of language by allowing peers to construct meaning. Practical support for peer review comes from learner-centered classes in which students' involvement cannot be found in ordinary teacher-fronted classes.

The purpose of the present study is to deal with two limitations stressed by Guénette (2007) and Mendonça and Johnson (1994) as the problems with most of the feedback studies in EFL context. The first issue is the language proficiency level because as Guénette states, most of the studies in L1 context deal with advanced learners. This was the case with Mendonça and Jonson who delimited their study to advanced learners in ESL context. The present study intends to investigate the effect of language proficiency level on the peer negotiation and to find if it has meaningful effect on high and low proficient peers. In addition, to complement and solidify Mendonça and Johnson's findings which was descriptive, the present study aims to find statistically significant difference between high and low proficient groups. The second aim is to investigate if the proper preparation of peers can lessen the possible negative cultural effect (Carson \& Nelson, 1996) on the peer negotiation.

Depending on whether the negotiation categories are shared by writers or reviewers, or whether they are used exclusively by the writers or exclusively by the reviewers, the present study aims to answer the following research questions:

1. Is there any significant difference in the frequency means of negotiation categories used by writers and reviewers in high proficient groups?

2. Is there any significant difference in the frequency means of negotiation categories used by writers and reviewers in low proficient groups?

3. Is there any significant difference in the frequency means of negotiation categories used by writers in the proficient and the low proficient groups?

4. Is there any significant difference in the frequency means of negotiation categories used by the reviewers in the proficient and the low proficient groups? 
Mowlaie, B. \& Maftoon, P. (2015). The effect of language proficiency on the negotiation in peer review in EFL context. Global Journal of Foreign Language Teaching. 5(1), 52-64.

\section{Method}

\subsection{Participants}

The participants in this study were 80 male and female adult EFL learners in two pre-existing intact classes in high and low language proficiency levels with 40 participants in the lower and 40 in the upper proficiency group. The classes were selected from Islamic Azad University, South Tehran Branch, and Kish Language School. The average age of the participants was around 22 and they were of mixed socio economic status. They were exposed to English outside of the writing classes since they had to study English in other classes as the requirement for their education. Passive consent was used in this study which involved subjects not opting out or not objecting to the study. They shared the same L1, Persian.

\subsection{Design}

The design used in this study was quasi-experimental because as stated by Dornyei (2007), establishing firm cause-effect relationships, as in this study, is surprisingly difficult in EFL context because in real life nothing happens in isolation, and due to complexities involved in exchanging feedback, it was hard to disentangle the interference of various extraneous variables with the variables of interest. Another reason was the long data collection period which took around three months. Using pre-existing intact classes completely obviated attrition or experimental mortality as a major problem because the researcher-teacher was able to have nearly all of his participants in both groups for the whole treatment phase. The generalizability problem was resolved too. Because the treatment occurred in authentic learning environments using genuine class groups, the reduced external validity was not a serious issue.

\subsection{Instrument}

The first instrument used in this study was a comprehensive paper-based language proficiency test called Babel English Language Placement Tests to establish the language proficiency levels of participants before the treatment. The testing required no more than 70 minutes of trainee time and did not require any specialist testers to administer it. This test consisted of four tests of equal difficulty. Each test contained four sections of twenty five reading, grammatical and lexical items. The tests were in multiple-choice format (to ensure rapid marking) and consisted of items measuring the recognition of correct responses to reading prompts, grammatical forms and lexical choices in context. As mentioned in the test manual, all items had been extensively pre-tested with students from a variety of first-language backgrounds. The second instrument was expository mode of writing because it is the most frequently used type of writing by students in colleges and universities (Smalley, Ruetten \& Koshered, 2001). The third instrument was an evaluation checklist adapted from White and McGovern (1994). It included points on main idea, purpose, content, structure of text, cohesion, vocabulary, grammar, and mechanical accuracy. The fourth instrument was MP3 tape recorders to record the peers' negotiations of meaning. The final instrument used to analyze the data was the negotiation categories devised by Mendonça and Johnson (1994; see Appendix). Negotiations were divided into five categories (with two sub-categories): questions, explanations, restatements, suggestions, and grammar corrections. A distinction was made between writer-generated and reviewer-generated comments.

\subsection{Data Collection}

Participants were instructed to write a first draft on a topic in 35 to 40 minutes in around 200 words in class. They submitted their writings by the end of the class. On the subsequent week, the texts were returned to the peer groups with specified members and roles. Based on White and McGovern's (1994) checklist, each member in the group read their peers' texts and gave their written feedback on different aspects in around15 minutes. This was followed by the oral 
Mowlaie, B. \& Maftoon, P. (2015). The effect of language proficiency on the negotiation in peer review in EFL context. Global Journal of Foreign Language Teaching. 5(1), 52-64.

discussion and negotiation of problems between the peers that was tape-recorded for further analysis. The negotiation part lasted approximately 15 to 20 minutes. The rationale for written preceding the oral feedback was to give learners some time to organize their oral feedback which because of the nature of speaking especially in EFL context would put pairs under stress. There was no interference from the teacher-researcher in negotiation between the peers because it was postulated that it was only the actual participants themselves who could reveal the meanings and interpretations of their experiences and actions. After negotiation, they submitted the papers to the teacher. Although each peer was free to choose his or her peer to take care of the affective variable, the place and atmosphere of negotiation were kept constant throughout the treatment. To optimize the negotiation and because of the necessity and importance of training and preparation (Berg, 1999; Mendonca \& Johnson, 1994; Stanley, 1992; Zamel, 1985), participants went through a period of training both prior and during the treatment about how to handle moves such as arriving at a consensus, expressing criticisms, and suggesting in a clear, comprehensible, yet tactful way.

The procedure was repeated for three times. Contrary to Mendonça and Johnson (1994) whose participants were free to choose their topics, in the present study all participants were required to write on the same topics because it was postulated that different topics would cause additional and uncontrolled difference because of participants' different backgrounds. The topics were: 1 . Choose a person you admire and explain why he/she is you role model. 2 . Thousands of people are killed in road accidents each year. What are the reasons and how can the death rate be reduced? 3. Air pollution is one of the major health problems in big cities. What solutions can you propose to solve this problem?

The data of interest for the present study included the audio-taped oral negotiation between the peers (writers and reviewers) in both high and low proficient groups. A total of almost twenty hours of conversation was collected, but due to low quality, only eight hours of data could be used. Using Mendonça and Johnson's (1994) category, the incidence of negotiation moves was calculated by counting each instance of negotiation categories. The transcription was done using standard orthography. Multitier format (Edwards, 2003) was used for coding which involved placing codes or annotations on separate lines beneath the datum they clarified. This format enabled the researcher to access each type of information independently from the others in an efficient manner. Because of the open-endedness and changing nature of transcription (Ehlich, 1993, as cited in Edwards, 2003), the recordings were listened more than once throughout the period of data collection and transcripts were updated accordingly. In spite of this, not all of the nuances could be captured because of the low sound quality.

\section{Data Analysis}

Because language proficiency level was the independent variable, an independent-sample ttest was conducted to certify the statistically meaningful difference between participants in high and low proficiency groups. As shown in Tables 1 and 2, there was a significant difference in scores for high proficient learners $(M=27.27, S D=1.886)$ and low proficient learners $(M=$ $39.10, \mathrm{SD}=2.774) ; \mathrm{t}(78)=53.567$, sig $=.00$ (two-tailed).

Table1. Group Statistics of Proficiency Level

\begin{tabular}{llllllll}
\hline & category & $N$ & Mean & SD & \multicolumn{2}{c}{ Skewness } \\
& & & & & Statistic & Std. Error \\
\hline \multirow{2}{*}{ Proficiency } & High & 40 & 67.27 & 1.886 & .285 & .374 \\
& Low & 40 & 39.10 & 2.774 & -.094 & .374 \\
\hline
\end{tabular}


Table 2. Independent Samples Test between High and Low Proficient Groups

\begin{tabular}{|c|c|c|c|c|c|c|c|c|}
\hline \multicolumn{2}{|c|}{$\begin{array}{l}\text { Levene's Test } \\
\text { for Equality of } \\
\text { Variances }\end{array}$} & \multicolumn{7}{|c|}{ t-test for Equality of Means } \\
\hline \multirow[t]{2}{*}{$\mathrm{F}$} & \multirow[t]{2}{*}{ Sig. } & \multirow[t]{2}{*}{$\mathrm{t}$} & \multirow[t]{2}{*}{$d f$} & \multirow[t]{2}{*}{$\begin{array}{l}\text { Sig. } \\
(2- \\
\text { tailed })\end{array}$} & \multirow[t]{2}{*}{$\begin{array}{l}\text { Mean } \\
\text { Difference }\end{array}$} & \multirow[t]{2}{*}{$\begin{array}{l}\text { Std. Error } \\
\text { Difference }\end{array}$} & \multicolumn{2}{|c|}{$\begin{array}{l}95 \% \text { Confidence } \\
\text { Interval of the } \\
\text { Difference }\end{array}$} \\
\hline & & & & & & & Lower & Upper \\
\hline \multirow[t]{2}{*}{8.169} & .005 & 53.567 & 78 & .000 & 28.175 & .526 & 27.128 & 29.222 \\
\hline & & 53.567 & 69.025 & .000 & 28.175 & 0526 & 27.126 & 29.224 \\
\hline
\end{tabular}

$1^{*}$. Equal variances assumed $2 *$. Equal variances not assumed

Three forms of comparisons were conducted in negotiation. In those categories shared by the writers and reviewers, comparison was made between the writers and the reviewers in high and low proficient groups separately. In those categories used mainly by the writers, writers in the high and low proficiency groups were compared with each other. Likewise, in the category used mainly by the reviewers, the reviewers in high and low proficiency groups were compared with each other.

Based on the research question, the first null hypothesis states that there is no significant difference in the frequency means of negotiation categories used by the writers and the reviewers in high proficient groups.

As illustrated in Table 3, in high proficient groups, in all four categories, the frequency means of negotiation categories used by the reviewers were higher than those used by the writers. The biggest difference was found in suggestion with $M=5.98$ for the reviewers and $M=1.80$ for the writers. Explanation of opinion took the second biggest difference with $M=9.05$ for the reviewers and $M=7.10$ for the writers. Grammar correction with $M=3.35$ for the reviewers and mean $=2.00$ for the writers was in the third position. The minimum difference in the frequency means belonged to restatement with $\mathrm{M}=2.75$ for the writers and mean $=3.80$ for the reviewers.

Table 3. Descriptive Statistics for Independent-Sample T-Test between the Writers and the Reviewers in High Proficient Group

\begin{tabular}{llllllllc}
\hline & W/R & N & Mean & SD & SEM & \multicolumn{2}{c}{$\begin{array}{c}\text { Skewness } \\
\text { Statistic }\end{array}$} & $\begin{array}{c}\text { Standard } \\
\text { Error }\end{array}$ \\
& & & & & & & & \\
Restatement & Writer & 20 & 2.75 & 2.900 & .648 & 1.018 & .512 \\
& Reviewer & 20 & 3.80 & 3.088 & .691 & .697 & .512 \\
Suggestion & Writer & 20 & 1.80 & 2.858 & .639 & 1.016 & .512 \\
& Reviewer & 20 & 5.95 & 3.546 & .793 & .612 & .512 \\
Grammar Correction & Writer & 20 & 2.00 & 1.974 & .441 & .411 & .512 \\
Explanation of & Reviewer & 20 & 3.35 & 2.183 & .488 & .680 & .512 \\
Opinion & Writer & 20 & 7.10 & 4.553 & 1.018 & .668 & .512 \\
\hline & Reviewer & 20 & 9.05 & 6.057 & 1.354 & 1.097 & .512 \\
\hline
\end{tabular}

The following excerpt shows samples of the negotiation categories between the writer and the reviewers.

Reviewer: I cannot understand what you mean by sleeping policeman [request for explanation] 
Mowlaie, B. \& Maftoon, P. (2015). The effect of language proficiency on the negotiation in peer review in EFL context. Global Journal of Foreign Language Teaching. 5 
Mowlaie, B. \& Maftoon, P. (2015). The effect of language proficiency on the negotiation in peer review in EFL context. Global Journal of Foreign Language Teaching. 5(1), 52-64.

difference in frequency means belonged to restatement in which the difference between the writers and the reviewers was minimum $(M=3.8$ for the reviewers and $M=2.10$ for the writers).

Table 5. Descriptive Statistics for Independent-Sample T-Test between the Writers and the Reviewers in Low Proficient Group

\begin{tabular}{llllllll}
\hline & & & & & & \multicolumn{2}{c}{ Skewness } \\
& W. R & $N$ & Mean & SD & SEM & & Standard \\
& & & & & & Statistic & Error \\
\hline \multirow{3}{*}{ Restatement. } & Writer & 20 & 2.10 & 1.586 & .355 & .171 & .512 \\
& Reviewer & 20 & 3.80 & 2.526 & .565 & -.142 & .512 \\
Suggestion & Writer & 20 & .75 & 1.118 & .250 & 1.003 & .512 \\
Grammar Correction & Reviewer & 20 & 8.00 & 8.608 & 1.925 & 1.065 & .512 \\
Explanation of & Writer & 20 & .60 & 1.142 & .255 & 1.080 & .512 \\
Opinion & Reviewer & 20 & 2.75 & 2.197 & .491 & .552 & .512 \\
& Writer & 20 & 2.20 & 1.576 & .352 & .889 & .512 \\
& Reviewer & 20 & 7.75 & 4.865 & 1.088 & .879 & .512 \\
\hline
\end{tabular}

As Table 6 shows, contrary to the high proficient group, in the low proficient group, there was a significant difference in restatement between the writers and the reviewers, $t(31.969)=$ -2.549 , sig. $=.016$ (two-tailed). The case with suggestion was similar to the high proficient group: there was a significant difference between the writers and reviewers, $t(38)=-3.735$, sig. = .001 (two-tailed). There was also a significant difference in the frequency means of grammar correction between the writers and the reviewers, $t(28.572)=-3.882$, sig. $=.001$ (two-tailed). Opposite the case with high proficient group, there was also a significant difference in the frequency means of explanation of opinion between the writers and the reviewers, $t(22.945)=-4.853$, sig. $=.000$ (two-tailed). Therefore, in the low language proficient group, there was a significant difference between the writers and the reviewers in all four negotiation categories.

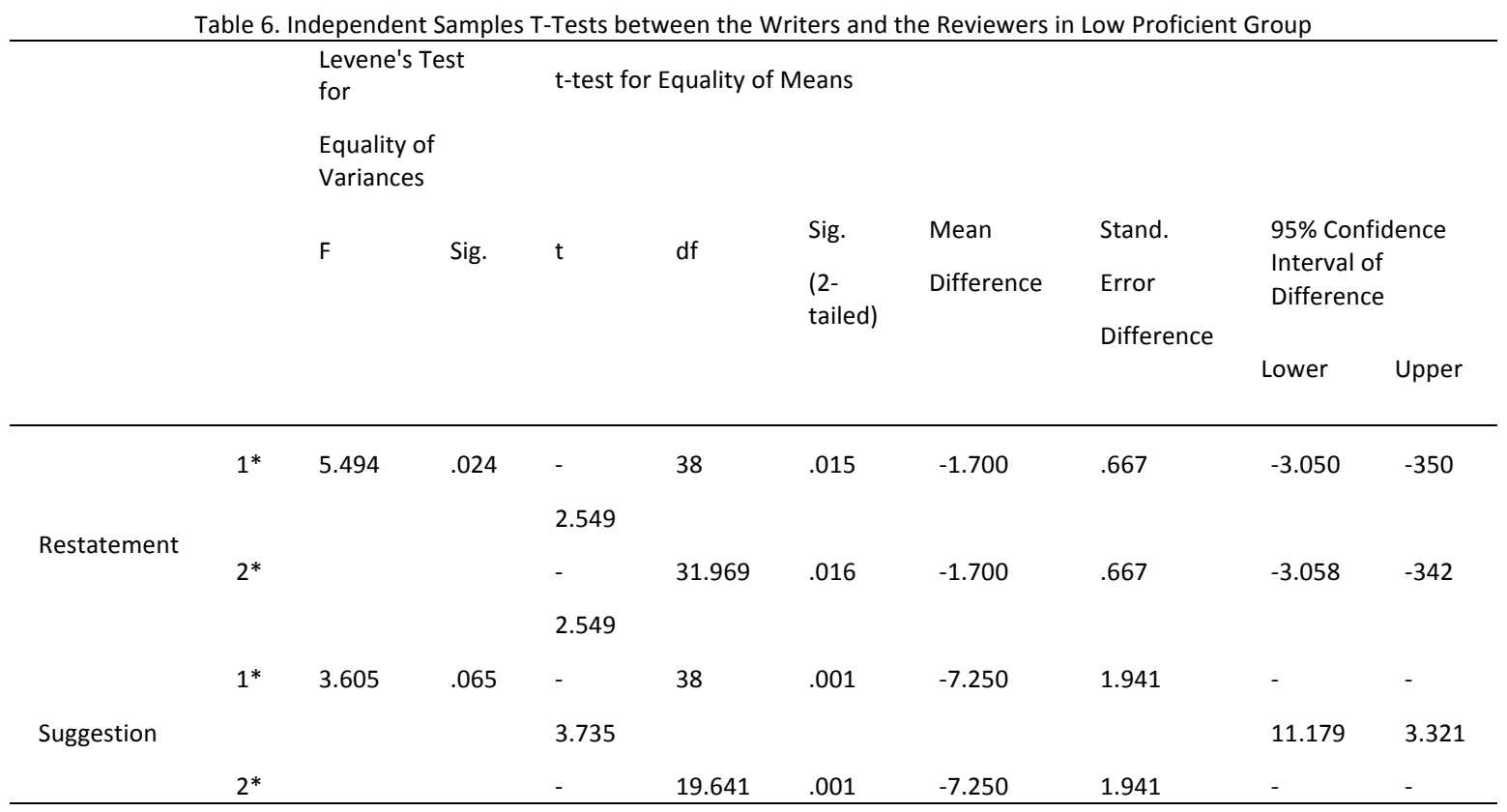




\begin{tabular}{|c|c|c|c|c|c|c|c|c|c|c|}
\hline & & & & 3.735 & & & & & 12.304 & 3.196 \\
\hline & $1^{*}$ & 8.426 & .006 & - & 38 & .000 & -2.150 & .554 & -3.271 & - \\
\hline Grammar & & & & 3.882 & & & & & & 1.029 \\
\hline \multirow[t]{3}{*}{ Correction } & $2^{*}$ & & & - & 28.572 & .001 & -2.150 & .554 & -3.283 & - \\
\hline & & & & 3.882 & & & & & & 1.017 \\
\hline & $1^{*}$ & 10.210 & .003 & - & 38 & .000 & -5.550 & 1.144 & -7.865 & - \\
\hline Explanation & & & & 4.853 & & & & & & 3.235 \\
\hline \multirow[t]{2}{*}{ of Opinion } & $2^{*}$ & & & - & 22.945 & .000 & -5.550 & 1.144 & -7.916 & - \\
\hline & & & & 4.853 & & & & & & 3.184 \\
\hline
\end{tabular}

$1^{*}$. Equal variances assumed $2 *$. Equal variances not assumed

The third null hypothesis states that there is no significant difference in the frequency means of negotiation categories used by writers in the high and the low proficient groups. As illustrated in Table 7, there was a mixed result in this part. The writers in the low proficient group $(M=$ 1.40) used comprehension check more than the writers in the high proficient group $(M=.95)$. However, there was a different case with explanation category because the writers in the high proficient groups $(M=12.65)$ used this category more than the writers in the low proficient group $(M=9.3)$.

Table 7. Descriptive Statistics for Independent-Samples T-Test between the Writers in the Proficient and the Low Proficient Groups

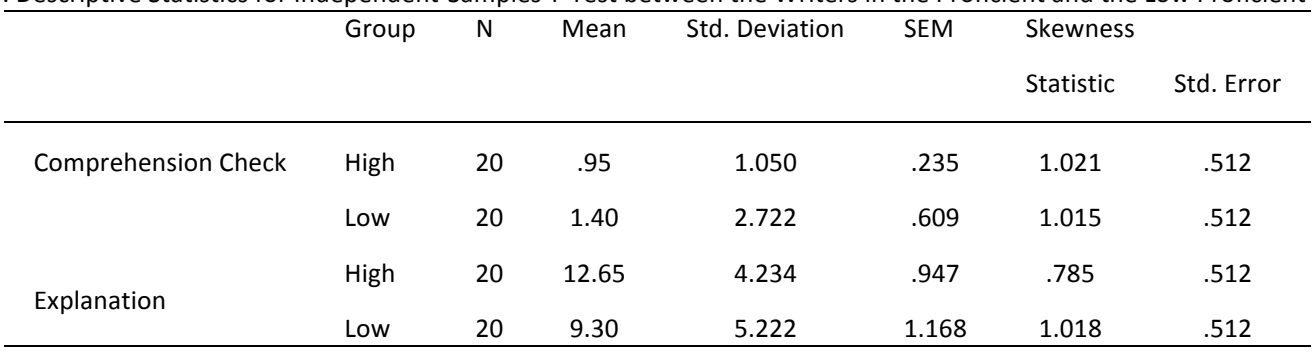

As presented in Table 8, there was no significant difference in comprehension check between the writers in the high, and the writers in the low proficient groups, $t(24.532)=-.690$, sig. $=.497$ (two-tailed). However, writers in the high proficient groups used this category statistically significantly from the writers in the low proficient group there is a significant difference in the explanation category used by the writers in the high and the writers in the low proficient groups, $\mathrm{t}(38)=2.228$, sig. $=.032$ (two-tailed).

\begin{tabular}{|c|c|c|c|c|c|c|c|c|c|c|}
\hline & & \multicolumn{2}{|c|}{$\begin{array}{l}\text { Levene's Test } \\
\text { for } \\
\text { Equality of } \\
\text { Variances }\end{array}$} & \multicolumn{7}{|c|}{ t-test for Equality of Means } \\
\hline & & \multirow[t]{2}{*}{$\mathrm{F}$} & \multirow[t]{2}{*}{ Sig. } & \multirow[t]{2}{*}{$\mathrm{t}$} & \multirow[t]{2}{*}{ df } & \multirow{2}{*}{$\begin{array}{l}\text { Sig. } \\
(2- \\
\text { taile } \\
\text { d) }\end{array}$} & \multirow[t]{2}{*}{$\begin{array}{l}\text { Mean } \\
\text { Difference }\end{array}$} & \multirow[t]{2}{*}{$\begin{array}{l}\text { Std. Error } \\
\text { Differenc } \\
\text { e }\end{array}$} & \multicolumn{2}{|c|}{$\begin{array}{l}\text { 95\% Confidence } \\
\text { Interval } \\
\text { of Difference }\end{array}$} \\
\hline & & & & & & & & & Lower & Upper \\
\hline \multirow{3}{*}{$\begin{array}{l}\text { Comprehe } \\
\text { nsion } \\
\text { Check }\end{array}$} & $1^{*}$ & 4.306 & .04 & -.690 & 38 & .495 & -.450 & .652 & -1.771 & .871 \\
\hline & & & 5 & & & & & & & \\
\hline & $2^{*}$ & & & -.690 & 24.532 & .497 & -.450 & .652 & -1.795 & .895 \\
\hline \multirow{2}{*}{$\begin{array}{l}\text { Explanatio } \\
\mathrm{n}\end{array}$} & $1^{*}$ & .156 & .69 & 2.228 & 38 & .032 & 3.350 & 1.503 & -.307 & 6.393 \\
\hline & 2* & & & 2.228 & 36.441 & .032 & 3.350 & 1.503 & -.302 & 6.398 \\
\hline
\end{tabular}


Mowlaie, B. \& Maftoon, P. (2015). The effect of language proficiency on the negotiation in peer review in EFL context. Global Journal of Foreign Language Teaching. 5 
Mowlaie, B. \& Maftoon, P. (2015). The effect of language proficiency on the negotiation in peer review in EFL context. Global Journal of Foreign Language Teaching. 5(1), 52-64.

The effect of generating most of the negotiation categories by the reviewers in the present study is explained by Lundstrom and Baker (2009) whose analysis indicates that the feedback givers, who focus solely on reviewing peers' writing, make more significant gains in their own writing over the course of the semester than do the receivers, who focus solely on how to use peer feedback. Another support from the same study is that givers at the lower language proficiency level make more gains than those at higher language proficiency levels. They state that the beginning students' greater gain in overall writing ability can be interpreted to mean that students at higher proficiency levels do not benefit as much from peer review as do beginning students. Lundstrom and Baker suggest several reasons may account for this difference in significant writing improvement between the high and low proficient students. One possible reason is that students at the beginning level, because their language skills are less developed, have more room for improvement, possibly due to floor effect, than do the high proficient learners, possibly due to ceiling effect, and therefore, the effects of new skills they develop result in a greater relative improvement in their writing ability. This might be the reason why the beginning giver group has higher gains than does the receiver group. Also, students at the higher language proficiency level may have had more experience with peer review and negotiation than those at the lower level, pushing them further along the learning curve. This could mean that the more advanced students have already received the greatest initial benefits to be gained from peer review, and therefore, the improvement they make seem less significant relative to where they started.

The possible negative effect of some EFL culture is another point of interest. Contrary to assertions made by Carson and Nelson (1996), and Nunan, (2001) on the negative effect of EFL cultures characterized by high-structure, transmission modes of learning in which teachers control the action which might act against the efficiency of peer feedback in general and oral negotiation in particular, it can be stated that this probable negative effect can be lessened to a remarkable degree by appropriate use of preparation and training of peers. The high frequency of most of the negotiation categories used by the reviewers indicates the significance and success of training participants to ask questions that generate response from the writers and that are revision-oriented so that there is a meaningful discussion about the content, rhetoric and grammar of the text. Although Stanley (1992) showed training peers caused the negotiation categories to be balanced between the writers and the reviewers, in the present study, training did not have the balancing effect in the negotiation and, consequently, the reviewers dominated the discussions in generating most of the negotiation categories. However, in both cases, training did have its positive effect.

Besides the points which focused on the macro structure, content, or the general organization of the text, the equally high frequency of negotiation on grammar and its significant difference between the reviewers and the writers in both high and low proficient group indicates that both reviewers and writers viewed grammar of equal importance in negotiating for revision. Paying equal attention to content and form in revision in the same draft of writing in EFL context is supported by researchers like Fathman and Whalley (1990), and Kepner (1991) who believe that the effect of this combined revision outweighs that of focusing exclusively on content which might be the norm in L1 writing with native or advanced writers. In EFL context, surface revision can and should be regarded as a means to improve not only EFL learners' writing skill, but also their language in general. Perhaps that is why learners consider feedback in grammar from either their teacher or peer of high importance (Oliver \& Mackey, 2003) and resist against the counterargument in putting the premium on the content revision and marginalizing the surface revision (Al Hazmi \& Schofield, 2007)

The rationale proposed by Mendonca and Johnson (1994) for EFL learners' interests in grammar is their belief that correct form is more important than the effective communication of meaning. Of course Stanley (1992) believes that proper coaching of L2 writers on ways to be effective peer evaluators can enable them to be more engaged in the peer review task, communicate more effectively about their peers' writing, and make clearer suggestions for revisions. However, the default according to Leki (1990) seems to be focusing on surface errors and ignoring the broader issues of meaning. 
Mowlaie, B. \& Maftoon, P. (2015). The effect of language proficiency on the negotiation in peer review in EFL context. Global Journal of Foreign Language Teaching. 5(1), 52-64.

\section{Conclusion}

The findings of this study can have important pedagogical implications not only for L2 writing, but also for speaking, and cooperative learning since peer review and peer negotiation involves all of these activities. It also offers peer feedback as a viable alternative to teacher-fronted classes with high number of students where class management can be an issue. Based on the result, by relinquishing part of their roles to the learners and involving them in the process of negotiation, EFL writing teachers can hold their students accountable for what they are expected to learn. Exchanging feedback in the form of negotiation can be an enabling practice for EFL learners to practice critical argumentation which does not have to be restricted to writing classes. It can also increase learners' tolerance to listen to their peers as the real audience which besides making the task authentic (Mangelsdorf, 1989), it can push them to speak and improve their output (Swain, 1985).

This study was a response to the question whether the same pattern of negotiation can be seen in different proficiency groups in an EFL context. The result shows that with proper training and preparation, it can be a viable and pedagogically a beneficial act which can override the cultural barriers and concerns raised by Carson and Nelson (1996), and Nunan, (2001)

\section{References}

Al Hazmi, S., \& Schofield, P. (2007). Enforced revision with checklist and peer feedback in EFL writing: The example of Saudi University students. Scientific Journal of King Faisal University, 8(2), 237-267.

Berg, C. (1999). The effects of trained peer response on ESL students' revision types and writing quality. Journal of Second Language Writing, 8, 215-241.

Carson, J., \& Nelson, G. (1996). Chinese students' perceptions of EFL peer response group interaction. Journal of Second Language Writing, 5(1), 1- 19.

Cazden, C. B. (1988). Classroom discourse: The language of teaching and learning. Portsmouth, NH: Heinemann.

Dornyei, Z. (2007). Research methods in applied linguistics. Oxford: Oxford University Press.

Edwards, J. E. (2003). The transcription of discourse. In D. Schiffrin, D. Tannen, \& H. Hamilton (Eds.), The handbook of discourse analysis (pp. 321-349). Oxford: Blackwell Publication.

Ehlich, K. (1993). HIAT: A transcription system for discourse data. Talking data: Transcription and coding in discourse research, 123-148.

Fathman, A. K., \& Whalley, E. (1990). Teacher response to student writing: Focus on form versus content. In B. Kroll (Ed.), Second Language Writing (pp.178-190). Cambridge: Cambridge University Press.

Flower, L., \& Hayes, J. R. (1981). A cognitive process theory of writing. College Composition and Communication, 32(4), 365-87.

Guénette, D. (2007). Is feedback pedagogically correct? Research design issues in studies of feedback on writing. Journal of Second Language Writing, 16, 40- 53.

Kepner, C. G. (1991). An experiment in the relationship of types of written feedback to the development of second-language writing skills. The Modern Language Journal, 75(3), 305-313.

Kroll, B. (1991). Teaching writing in the ESL context. In M. Celce-Murcia (Ed.), Teaching English as a second or foreign language (pp. 245-263). New York: Newbury House.

Leki, I. (1990). Coaching from the margins: Issues in written response. In B. Kroll, (Ed.), Second language writing (pp. 25-86). Cambridge: Cambridge University Press.

$\mathrm{Li}, \mathrm{C} .(2006)$. The impact of teacher involved peer feedback in the ESL writing class. Sino-US English Teaching, 3(5), 28-32.

Lightbown, P. M., \& Spada, N. (2006). How languages are learned ( $3^{\text {rd }}$ ed.). Oxford: Oxford University Press.

Lundstrom, K., \& Baker, W. (2009). To give is better than to receive: The benefits of peer review to the reviewer's own writing. Journal of Second Language Writing, 18, 30-43.

Mangelsdorf, K. (1989). Parallels between speaking and writing in second language acquisition. In D. M. Johnson \& D. H. Roen (Eds.), Richness in writing: Empowering

ESL students (pp. 134-145). White Plains, NY: Longman. 
Mangelsdorf, K. (1992). Peer reviews in the ESL composition classroom: What do the students think? ELT Journal, 46, 274-284.

Mendonça, C. O., \& Johnson, K. E. (1994). Peer review negotiations: Revision activities in ESL writing instruction. TESOL Quarterly, 28, 745-769.

Nunan, D. (2001). English as a global language. TESOL Quarterly, 35, 605-606.

Oliver, R., \& Mackey, A. (2003). Interactional context and feedback in child ESL classrooms. Modern Language Journal, 87(4), 519. Abstract retrieved June 20, 2011 from: www.jstor.org/stable/1192801

Richards, J. C., \& Rodgers, T. S. (2001). Approaches and methods in language teaching (2nd ed.). Cambridge: Cambridge University Press.

Riddle, D. (2003). Teaching English as a foreign/second language. London: Teach Yourself.

Smalley, R. L., Ruetten, M. K., \& Koshered, J. R. (2001). Refining composition skills: Rhetoric and grammar (5th ed.). Boston: Heinle and Heinle.

Stanley, J. (1992). Coaching student writers to be more effective peer evaluators. Journal of Second Language Writing, 1(3), 217-233.

Swain, M. (1985). Communicative competence: Some roles of comprehensible input and comprehensible output in its development. Input in second language acquisition, 15, 165-179.

Vygotsky, L. S. (1986). Thought and language. Cambridge, MA: MIT Press.

White, R. and McGovern, D. (1994). Writing: A Student's Book. English for Academic Study Series. Hemel Hempstead, Hertfordshire: Prentice Hall Europe.

Zamel, V. (1985). Responding to students' writing. TESOL Quarterly, 19, 79-101. 
Mowlaie, B. \& Maftoon, P. (2015). The effect of language proficiency on the negotiation in peer review in EFL context. Global Journal of Foreign Language Teaching. 5(1), 52-64.

Appendix: Mendonça and Johnson's (1994) Coding Categories of Negotiations and Definitions

\begin{tabular}{|c|c|c|}
\hline No & Coding Category & Definition \\
\hline \multirow[t]{3}{*}{1} & question & \\
\hline & a. Request for explanation & $\begin{array}{l}\text { Reviewers try to get further explanation of what writers have said or what is } \\
\text { not clear to them in the essays (e.g., an unknown term, an idea). } \\
\text { This request can be either an explicit question or a statement saying that } \\
\text { something is not clear. }\end{array}$ \\
\hline & b. Comprehension check & $\begin{array}{l}\text { Writers ask reviewers if they have understood the meaning of a term or idea } \\
\text { in the essay. Also, writers and reviewers ask each other if they have } \\
\text { understood what has been said. }\end{array}$ \\
\hline \multirow[t]{4}{*}{2} & Explanation & \\
\hline & $\begin{array}{l}\text { a. Explanation of an unclear } \\
\text { point in the text }\end{array}$ & Writers explain the meaning of a term or idea that is not clear to reviewers \\
\hline & b. Explanation of opinion & $\begin{array}{l}\text { Reviewers or writers explain why they think a given term or idea is or is not } \\
\text { clear and should or should not be used in the essay }\end{array}$ \\
\hline & $\begin{array}{l}\text { c. Explanation of the } \\
\text { content }\end{array}$ & $\begin{array}{l}\text { Writers explain the subject of their essay to reviewers, that is what their } \\
\text { essay is about }\end{array}$ \\
\hline 3 & Restatements & $\begin{array}{l}\text { Reviewers or writers restate (summarize or rephrase) what has been written } \\
\text { or said to show understanding or re-read sections of the essay }\end{array}$ \\
\hline 4 & Suggestions & $\begin{array}{l}\text { Reviewers or writers suggest ways to change the words, content, or } \\
\text { organization of the essay }\end{array}$ \\
\hline 5 & Grammar Correction & $\begin{array}{l}\text { Reviewers or writers correct grammatical structures in the essay. Grammar } \\
\text { correction can be related to subject-verb agreement, verb tense, singular- } \\
\text { plural, etc. }\end{array}$ \\
\hline
\end{tabular}

Bahram Mowlaie, since 2007, has been a faculty member of English language department of Islamic Azad University of South Tehran. He is a PhD candidate in TESOL at Islamic Azad University, Science and Research Campus, Tehran, Iran. His primary research interest concerns writing in second language. Email: bahrammowlaie@yahoo.com

Parviz Maftoon is Associate Professor of teaching English at Azad University, Science and Research Campus, Tehran, Iran. He received his PhD degree from New York University in 1978 in TESOL. His primary research interests concern EFL writing, second language acquisition, and syllabus design. He has published and edited a number of research articles and books. He is currently on the editorial board of some language journals in Iran. 